University of Nebraska - Lincoln

DigitalCommons@University of Nebraska - Lincoln

Faculty Papers and Publications in Animal

Science

Animal Science Department

January 1961

\title{
COMPONENTS OF VARIANCE ASSOCIATED WITH MILK AND FAT RECORDS OF ARTIFICIALLY SIRED HOLSTEIN DAUGHTERS
}

\author{
L. Dale Van Vleck \\ University of Nebraska-Lincoln, dvan-vleck1@unl.edu \\ L. H. Wadell \\ Cornell University \\ C. R. Henderson \\ Cornell University
}

Follow this and additional works at: https://digitalcommons.unl.edu/animalscifacpub

Part of the Animal Sciences Commons

\footnotetext{
Van Vleck, L. Dale; Wadell, L. H.; and Henderson, C. R., "COMPONENTS OF VARIANCE ASSOCIATED WITH MILK AND FAT RECORDS OF ARTIFICIALLY SIRED HOLSTEIN DAUGHTERS" (1961). Faculty Papers and Publications in Animal Science. 317.

https://digitalcommons.unl.edu/animalscifacpub/317

This Article is brought to you for free and open access by the Animal Science Department at DigitalCommons@University of Nebraska - Lincoln. It has been accepted for inclusion in Faculty Papers and Publications in Animal Science by an authorized administrator of DigitalCommons@University of Nebraska - Lincoln.
} 
L. D. Van Vleck, L. H. Wadell and C. R. Henderson. 1961. Components of Variance Associated with Milk and Fat Records of Artificially Sired Holstein Daughters. Journal of Animal Science20:812-816

Abstract: Components of variance are estimated for the three-way classification analysis of variance of DHIA reported first and second milk and fat records of artificially sired Holstein cows and of Owner-Sampler reported milk and fat records of artificially sired Holstein cows. The total variance of milk and fat records is partitioned into the following components with the approximate percent of total variance: sire, $6 \%$; year-season, $2 \%$; herd, $30 \%$; sire by year-season, $0 \%$; sire by herd, $1-2 \%$; herd by year-season, $6-8 \%$; sire by herd by year-season, $1-7 \%$; and residual, $50 \%$.

Copyright $\odot 1961$ American Society of Animal Science. Used by permission. 


\title{
COMPONENTS OF VARIANCE ASSOCIATED WITH MILK AND FAT RECORDS OF ARTIFICIALLY SIRED HOLSTEIN DAUGHTERS
}

\author{
L. D. VanVleck, L. H. Wadell, and C. R. Henderson \\ Cornell University, Ithaca, New York
}

$\mathrm{C}$ OMPONENTS of variance have been used widely in genetic and animal breeding applications. Some earlier reports of these techniques were by Lush et al. (1934), Bywaters (1937), Stonaker and Lush (1942), and Baker et al. (1943). Important animal breeding applications of variance component estimates are:

(1) to predict the breeding values of sires or dams and to predict real producing abilities of cows,

(2) to indicate sources of variation which should be considered in analyzing production records,

(3) to aid in the establishment of progeny testing programs, including design of the test, number of progeny required, and effectiveness of such programs, and

(4) to direct attention to sources of genetic by genetic, genetic by environmental, and environmental by environmental interactions which should be considered in the above programs.

The purpose of this paper is to present estimates of sire, herd, year-season, and interaction components of variance for first and second milk and fat DHIA records and OwnerSampler milk and fat records of artificially sired (AI) Holstein daughters.

\section{Data}

The data used in this study were first and second lactation, 305-day, 2x, M.E, DHIA milk and fat records of daughters of Holstein AI sires which were available at the New York Dairy Records Processing Laboratory. First records were defined to be those initiated prior to 35 months of age. Second records were defined to be either those started between 35 and 46 months of age, if no record was available in the files which was started prior to 35 months of age, or those started less than 14 months after a previous record which had started prior to 35 months of age. These arbitrary restrictions had to be imposed be- cause lactation number was not available for these records. The third group of records analyzed were Owner-Sampler records of Holstein AI daughters. No attempt was made to divide these records according to lactation number, but only the first centrally processed record per daughter was included in the analysis.

The data were classified by the year-season of calving, sire of the daughter making the record and the herd in which the record was made. Years were divided into three seasons - season one, December through March; season two, April through July; and season three, August through November. Sire groups were limited to those having 10 or more DHIA daughter records in the AI sire file of the Dairy Records Processing Laboratory as of September 1960 . This restriction does not imply that 10 daughter records of each sire were included in each analysis. Some of the 10 records may have been first records, others second records, and still others neither a first nor a second record. No restrictions were placed on number of records per herd.

\section{Analysis Procedure}

The mathematical model [model II of Eisenhart (1947)] assumed for each record was:

$$
\begin{gathered}
\mathrm{Y}_{\mathrm{ijkm}}=\mu+(\mathrm{s})_{\mathrm{i}}+(\mathrm{y})_{\mathbf{j}}+(\mathrm{h})_{\mathrm{k}}+(\mathrm{sy})_{\mathrm{ij}}+ \\
\quad(\mathrm{sh})_{\mathrm{ik}}+(\mathrm{yh})_{\mathrm{jk}}+(\mathrm{syh})_{\mathrm{ijk}}+(\mathrm{e})_{\mathrm{ijkm}} \\
(\mathrm{i}=\mathrm{l}, \ldots, \mathrm{I} ; \mathrm{j}=\mathrm{l}, \ldots, \mathrm{J} ; \mathrm{k}=\mathrm{l}, \ldots, \mathrm{K} ; \\
\left.\quad \text { and } \mathrm{m}=\mathrm{l}, \ldots, \mathrm{n}_{\mathrm{ijk}}\right)
\end{gathered}
$$

where $Y_{i j k m}$ is the record of the $m^{\text {th }}$ daughter of the $\mathrm{i}^{\text {th }}$ sire made during the $\mathrm{j}^{\text {th }}$ year-season in the $\mathrm{k}^{\text {th }}$ herd, $\mu$ is the fixed underlying population mean, and the $(\mathrm{s})_{\mathrm{i}},(\mathrm{y})_{\mathrm{j}},(\mathrm{h})_{\mathrm{k}},(\mathrm{sy})_{\mathrm{ij}}$, $(\mathrm{sh})_{\mathrm{ik}},(\mathrm{yh})_{\mathrm{jk}},(\mathrm{syh})_{\mathrm{ijk}}$, and $(\mathrm{e})_{\mathrm{ijkm}}$ are assumed to be independent and uncorrelated random effects with means zero and respective variances $\sigma_{\mathrm{s}}^{2}, \sigma_{\mathrm{y}}^{2}, \sigma_{\mathrm{h}}^{2}, \sigma_{\mathrm{sy}}^{2}, \sigma_{\mathrm{sh}}^{2}, \sigma_{\mathrm{yh}}^{2}, \sigma^{2}{ }_{\mathrm{syll}}$ and $\sigma^{2}{ }_{\mathrm{e}}$. The $(\mathrm{s})_{\mathrm{i}},(\mathrm{y})_{\mathrm{j}}$, and $(\mathrm{h})_{\mathrm{k}}$ refer to the effect of the $\mathrm{i}^{\text {th }}$ sire, $\mathrm{j}^{\text {th }}$ year-season, and $\mathrm{k}^{\text {th }}$ herd, respectively. Interaction effects are denoted similarly. The estimation procedure followed 
TABLE 1. SUBCLASS NUMBERS FOR THE COMPONENT OF VARIANCE ANALYSES OF FIRST AND SECOND DHIA RECORDS AND OF OWNERSAMPLER RECORDS

\begin{tabular}{lrrr}
\hline & $\begin{array}{r}\text { First } \\
\text { records }\end{array}$ & $\begin{array}{r}\text { Second } \\
\text { records }\end{array}$ & $\begin{array}{r}\text { Owner- } \\
\text { sampler } \\
\text { records }\end{array}$ \\
\hline Total number of records & 39728 & 37218 & 4068 \\
Number of sires & 236 & 230 & 182 \\
Number of year-seasons & 27 & 27 & 871 \\
Number of herds & 3932 & 3847 & 571 \\
$\begin{array}{l}\text { Number of sire by year-season } \\
\text { subclasses }\end{array}$ & 1881 & 1785 & 631 \\
$\begin{array}{l}\text { Number of sire by herd subclasses } \\
\text { Number of herd by year-season }\end{array}$ & 28981 & 26661 & 3248 \\
$\quad \begin{array}{l}\text { subclasses } \\
\text { Number of sire by year-season }\end{array}$ & 19048 & 19142 & 1323 \\
$\quad$ by herd subclasses & 36525 & 34730 & 3674 \\
\hline
\end{tabular}

Method One described by Henderson (1953). The assumptions given in the model are necessary for the property of unbiasedness to hold for the estimates. Although the year-season effects could easily be considered fixed effects, the complexity of the computations required to obtain unbiased estimates under these assumptions [ (see Method Three of Henderson (1953) ] led to the decision to use the random model even though all the requirements may not be quite satisfied.

The number of sire, herd, year-season, sire by herd, sire by year-season, herd by yearseason, and sire by herd by year-season subclasses are given in table 1 for first records, second records and Owner-Sampler records.

\section{Results and Discussion}

First, a consideration of causes of the effects described in the model should be mentioned. The sire component of variance is composed of additive genetic variance plus additive by additive, additive by additive by additive, etc. types of genetic variance. The year-season component is made up mainly of environmental contributions having as its genetic portion only that due to trend in genetic merit. The herd component of variance may be composed of both genetic and environmental portions.

The interaction components are slightly more complex in their interpretation. The sire by year-season component can be considered a genetic by environmental interaction if genetic trend is negligible. In other words, the differences between sires may be different under different weather, temperature, or feed supply conditions. The sire by herd variance component would be associated with a failure of the sire differences to be the same under different herd conditions. The possibility of herd by year-season interaction can be easily visualized. For example, all herds are not apt to react similarly to drough or low milk prices. The economic reserve of the dairyman may affect his reaction to these contingencies. The more economically stable owner is able to buy more and better feedstuffs and for a longer time in case of dry periods than a less prosperous owner who would cut back sooner on his purchases in order to balance costs against income. An interpretation of the threeway interaction component would be that sire by herd interactions are not the same for all year-seasons.

The percents of the total variation accounted for by each of the estimated variance components of first and second milk and fat DHIA records and milk and fat Owner-Sampler records are given in table 2 . It is noticed

TABLE 2. ESTIMATED PERCENTAGES OF TOTAL VARIATION OF FIRST AND SECOND DHIA RECORDS AND OWNER-SAMPLER RECORDS CONTRIBUTED BY SIRE, YEAR-SEASON, HERD, AND INTERACTION COMPONENTS

$$
\text { OF VARIANCE: }
$$

\begin{tabular}{|c|c|c|c|c|c|c|}
\hline \multirow{2}{*}{$\begin{array}{c}\text { Estimated } \\
\text { component } \\
\text { of } \\
\text { variance } \\
\end{array}$} & \multicolumn{2}{|c|}{ First records } & \multicolumn{2}{|c|}{ Second records } & \multicolumn{2}{|c|}{$\begin{array}{l}\text { Owner-sampler } \\
\text { records }\end{array}$} \\
\hline & Milk & Fat & Milk & Fat & Milk & Fat \\
\hline $\begin{array}{l}\sigma_{s}^{2} \\
\sigma_{y}^{2} \\
\sigma_{y}^{2} \\
\sigma_{s y}^{2} \\
\sigma_{s y}^{2} \\
\sigma_{\text {sh }}^{2} \\
\sigma_{\text {yh }}^{2} \\
\sigma^{2} \\
T_{0}^{2}\end{array}$ & $\begin{array}{r}5.89 \\
2.08 \\
29.14 \\
-0.75 \\
0.41 \\
6.86 \\
6.87 \\
49.51\end{array}$ & $\begin{array}{r}6.55 \\
2.59 \\
31.72 \\
-1.33 \\
0.64 \\
8.50 \\
3.50 \\
47.84\end{array}$ & $\begin{array}{r}5.91 \\
1.71 \\
28.22 \\
-0.43 \\
2.56 \\
5.95 \\
2.31 \\
53.78\end{array}$ & $\begin{array}{r}-6.77 \\
2.31 \\
30.40 \\
-1.03 \\
1.21 \\
6.74 \\
1.05 \\
52.55\end{array}$ & $\begin{array}{r}2.77 \\
1.56 \\
29.76 \\
2.12 \\
5.00 \\
5.55 \\
7.24 \\
46.00\end{array}$ & $\begin{array}{r}1.79 \\
1.83 \\
30.80 \\
3.15 \\
6.59 \\
5.70 \\
2.82 \\
47.32\end{array}$ \\
\hline $\begin{array}{l}\text { Total } \\
\text { variance }\end{array}$ & $68,220.50^{\mathrm{a}}$ & $9,135.93$ & $72,819.67^{\text {* }}$ & $10,123.13$ & $61,665.25^{\mathrm{a}}$ & $8,364.13$ \\
\hline
\end{tabular}

a Milk records were coded to the nearest $10 \mathrm{lb}$, 
immediately that the total variances of milk and fat records are composed of about the same percents of the different variance components. There is also much similarity between first and second records. If selection on first records of the AI daughters were practiced within herds then it would be expected that the variance of second records would be smaller than first records. Actually, the reverse is true in this analysis although the differences are not large. This result seems to indicate that variance component estimation in this AI population would not need to consider whether records were first records or second records.

The Owner-Sampler variance component analysis shows a slightly different picture. Total variance, especially of milk records, is much lower than for the DHIA records. Some differences also occur in the partitioning of the variance into components, but these may be due to sampling errors resulting from small numbers. It is certain that the sampling variances of the components estimated from the Owner-Sampler records are much larger than those from the other analyses, since only onetenth as many observations were available. There is, however, general agreement between the three analyses for the portions of variation contributed by herd effects and random error effects.

The estimates of variance components in the DHIA data agree well with those of other workers, e.g., Hickman and Henderson (1955) who, however, did not estimate the sire by year-season and sire by herd by year-season components. Their study included records of 3,912 cows in 1,094 herds by 126 sires. The contribution of the sire component to the total variance of about $6 \%$ in this study is in general agreement with the reports of Hickman and Henderson (1955) and Legates et al. (1956). The year-season contribution of about $2 \%$ is slightly lower than reported earlier. Of the attributable portions of total variance the herd component is the largest, accounting for about $30 \%$ of the total variation.

The two-way interactions involving sire effects, $\sigma^{2}{ }_{\mathrm{sy}}$ and $\sigma^{2}{ }_{\mathrm{sh}}$, are estimated to be nearly zero. Legates et al. (1956) as well as Hickman and Henderson (1955) have reported the sire by herd component to be negligible. The result of the present analysis tends to confirm the contention of Legates et al. (1956), that "nicking" effects probably are not important since these effects are likely to be included in the herd genetic by sire genetic interaction. Johnson et al. (1940) and Seath and Lush (1940) found little evidence to support the theory that "nicking" effects are important in dairy cattle breeding. Heizer $e t a l$. (1938), however, have reported otherwise. The year-season by herd interaction component is sizeable - about the same magnitude as the sire component. Possible reasons for this have been discussed above. Part of this component may be attributable to herd genetic by yearseason variation but it would seem more likely to be a result of herd environmental by yearseason environmental variation.

The three-way interaction component appears not to have been measured as consistently as the other components. One valuefirst milk records - is quite large. The other estimates are relatively small. If, in fact, the three-way interaction is important this would indicate that sire proofs under certain environmental conditions (specific herds in specific year-seasons) would be different from proofs under other environmental conditions. Actually, it seems more plausible that the sampling variances of the three-way interaction components are large (the average number of observations per filled three-way subclass was about 1.1) which could easily contribute to the seeming disparity of the estimates. The unexplained or residual variation, $\sigma^{2}$ e is by far the largest source of variation, about $50 \%$ of the total. This result is larger than that reported by Hickman and Henderson (1955) of $40 \%$ and lower than the $60-70 \%$ reported by Legates et al. (1956) for a sire by herd analysis ignoring year-season effects and interactions.

The sampling variances of these estimates are not known except for $\sigma^{2}$. The well known expression for the variance of $\sigma^{2}{ }_{e}$ is

\section{$\frac{2 \sigma^{4}}{\text { degrees of freedom }}$, for example, see Crump}

(1951) or Searle (1956). Searle (1958) has developed expressions for large-sample sampling variances of the components of variance estimated by Method One of Henderson (1953) for the two-way classification with non-orthogonal data. More recently Searle (1961) has developed similar expressions for the sampling variances of variance components estimated for the two-way nested classification with non-orthogonal data. Extension of the procedure to the three-way classification with unequal subclass numbers has not been accomplished.

The importance of herd, year-season, and 
herd by year-season effects is apparent from the results shown in table 2 . Consequently, sire evaluation programs should take into account these sources of variation which might influence the evaluation of sires when daughter records are unequally grouped in herds and year-seasons. The method, proposed by Henderson et al. (1954) and discussed more completely by Henderson (1956) and Heidhues et al. (1961), whereby daughter records are adjusted for contemporary records made in the same herd-year-season, is cited as an example of an attempt to remove these sources of variation. The $\frac{n}{n+1}$ adjustment for the stablemate average which Henderson et al. (1954) reported also makes use of herd and error components of variance.

The estimates of variance components in table 2 are of interest in planning progeny testing programs similar to those discussed by Dickerson (1942), Dickerson and Hazel (1944) and Robertson and Rendel (1950). Knowledge of sources of variation also aid in planning animal husbandry experiments, see for example Henderson (1960).

\section{Conclusions}

If the three-way classification analysis is appropriate for dairy production records of artificially sired Holstein cows, then approximately $50 \%$ of the variation is unaccounted for by sire, herd, year-season, and their two and three-way interaction components of variance.

Variance due to herd effects makes up a large part of the accountable variation, about $30 \%$ of the total.

The sire component corresponds to $6-7 \%$ of the total variance which agrees with earlier estimates.

The year-season component estimated in this study, $2 \%$, appears to influence the total variance less than other reports have indicated.

The sire by herd and sire by year-season components are very small which indicates there is little genetic by environmental interaction in dairy records under New York conditions.

The herd by year-season interaction seems to make up a significant portion, $6-8 \%$, of the total variation, suggesting that sire testing programs must consider this joint effect.

The variation of first records and second records of AI daughters appeared to be partitioned similarly. Hence, any selection prac- ticed on the basis of first records evidently did not greatly influence the components of variance of second records.

As expected the total variance of fat and milk records is composed of similar percentages of the variance components.

\section{Summary}

Components of variance are estimated for the three-way classification analysis of variance of DHIA reported first and second milk and fat records of artificially sired Holstein cows and of Owner-Sampler reported milk and fat records of artificially sired Holstein cows.

The total variance of milk and fat records is partitioned into the following components with the approximate percent of total variance: sire, $6 \%$; year-season, $2 \%$; herd, $30 \%$; sire by year-season, $0 \%$; sire by herd, $1-2 \%$; herd by year-season, $6-8 \%$; sire by herd by year-season, 1-7\%; and residual, $50 \%$.

\section{Literature Cited}

Baker, M. L., L. N. Hazel and C. F. Reinmiller. 1943. The relative importance of heredity and environment in the growth of pigs at different ages. J. Animal Sci. 2:3.

Bywaters, J. H. 1937. The hereditary and environmental portions of variance in weaning weights of Poland-China pigs. Genetics 22:457.

Crump, S. L. 1951. Present status of variance component analysis. Biometrics $7: 1$.

Dickerson, G. E. 1942. Experimental design for testing inbred lines of swine. J. Animal Sci. 1:326.

Dickerson, G. E. and L. N. Hazel. 1944. Effectiveness of selection on progeny performance as a supplement to earlier culling in livestock. J. Agr. Res. $69: 459$.

Eisenhart, C. 1947. The assumptions underlying analysis of variance. Biometrics. $3: 1$.

Heidhues, T., L. D. VanVleck and C. R. Henderson. 1961. Actual and expected accuracy of sire proofs under the New York system of sampling bulls. Z. Tierz. Zücht. Biol. (In press).

Heizer, E. E., M. C. Hervey, G. R. Barrett and G. W. Brandt. 1938. Nicking in dairy cattle. Proc. Am. Soc. Animal Production. p. 67.

Henderson, C. R. 1953. Estimation of variance and covariance components. Biometrics. 9:226.

Henderson, C. R. 1956. Cornell Research on methods of selecting dairy sires. Proc. New Zealand Soc. Animal Production 16:69.

Henderson, C. R. 1960. "Design and analysis of animal husbandry experiments" in Techniques and Procedures in Animal Production Research, American Society of Animal Production. p. 1.

Henderson, C. R., H. W. Carter and J. T. Godfrey. 1954. Use of the contemporary herd average in appraising progeny tests of dairy bulls. J. Animal Sci. 13:949.

Hickman, C. G. and C. R. Henderson. 1955. Components of the relationship between level of 
production and rate of maturity in dairy cattle. J. Dairy Sci. 38:883.

Johnson, L. A., W. Bartlett and L. Copeland. 1940.

A study of nicking in Jersey cattle. J. Dairy Sci. 23:709.

Legates, J. E., F. J. Verlinden and J. F. Kendrick. 1956. Sire by herd interaction in production traits in dairy cattle. J. Dairy Sci. 39:1055.

Lush, J. L., H. O. Hetzer and C. C. Culbertson. 1934. Factors affecting birth weights of swine. Genetics 19:329.

Robertson, A. and J. M. Rendel. 1950. The use of progeny testing with artificial insemination in dairy cattle. J. Genetics 50:21.
Searle, S. R. 1956. Matrix methods in components of variance and covariance analysis. Ann. Math. Stat. 27:737.

Searle, S. R. 1958. Sampling variances of estimates of components of variance. Ann. Math. Stat. 29: 167.

Searle, S. R. 1961. Variance components in the twoway nested classification. Ann. Math. Stat. (In press).

Seath, D. M. and J. L. Lush. 1940. "Nicking" in dairy cattle. J. Dairy Sci. 23:103.

Stonaker, H. H. and J. L. Lush. 1942. Heritability of conformation in Poland-China swine as evaluated by scoring. J. Animal Sci. 1:99. 